\title{
Core crack-filling by upstream gap-graded soils in zoned dams
}

\author{
R. Correia dos Santos \& L. Caldeira \\ Laboratório Nacional de Engenharia Civil (LNEC), Lisboa, Portugal \\ E. Maranha das Neves \\ Instituto Superior Técnico (IST), Lisboa, Portugal
}

\begin{abstract}
The crack-filling action in zoned dams, by a granular upstream zone located upstream of a damaged core, was investigated experimentally using the Crack-Filling Erosion Test (CFET). The CFET allows testing specimens with three distinct zones: the upstream zone, the core and the downstream filter. The results of a series of laboratory tests are presented. A total of 34 tests were conducted combining 6 coarse-grained (gap-graded) upstream materials, 2 core soils, and 2 granular filters. The results of the CFETs showed that the crack-filling action is mainly controlled by some of the properties of the upstream zone and of the filter. Core soils with moderately slow erosion, or less erodible, should not have an influence on the crack-filling action. This is so mainly because the filling mechanism should occur over a very short period. The factors influencing the crack-filling by an upstream material are addressed, and some rules which give dam engineers a tool for decision-making about the potential of a upstream material to limit progression of erosion in concentrated leaks are indicated.
\end{abstract}

\section{INTRODUCTION}

Internal erosion in cracks is one of the main causes of earth dam failures all over the world (Foster et al. 2000, ICOLD 2013). In some case studies of earth dams with a core, for example the Balderhead Dam (Vaughan and Soares 1982) or the Matahina Dam (Sherard 1973, Gillon 2007), despite the occurrence of concentrated leaks similar to those indicating development of imminent failure in the embankment, the flow has stopped or stabilised, allowing sufficient time for remedial actions to be effective. The most relevant issue distinguishing these incidents from those that lead to breach formation appears to be related to the presence of some types of materials upstream of the cracked core (Fell et al. 2008). These materials may induce the occurrence of two mechanisms, here named the flow-limiting action and the crack-filling action. This manuscript is focused on the latter. A detailed explanation about the flow-limiting action can be found in Correia dos Santos (2014) and Correia dos Santos et al. (2014).

The crack-filling action involves soil particles of an upstream material being washed into core cracks. These particles are transported by the concentrated flow from the interface with the cracked core, up to the downstream filter. This process fills the crack in the core, self-heals the concentrated leak in the core and stops the excessive concentrated leakage, limiting the progression of the internal erosion. A more detailed explanation of the crack-filling action can be found in Correia dos Santos et al. (2015a, 2015b).

There are almost no previous laboratory experiments focused on this particular topic. Previous laboratory tests are related only with the effectiveness of a particular fine sand (here termed as soil A0) to act as upstream filler (Maranha das Neves 1987, 1989, 1991).

In the interest of reducing costs while providing a safe design, it is valuable to investigate if other types of materials from borrow pits explored during construction can be used as effective upstream crack fillers. In particular, in this paper we investigate experimentally whether naturally occurring gap-graded materials with no (or few) fines can be trusted to provide the crack-filling function, and to what extent. When a crack forms in the core, high gradients may arise in the upstream zone. If the upstream zone is gap-graded, the finer fraction near the upstream soilcore interface susceptible to suffusion may then be transported into the damaged core, due to seepage forces through the space formed by the stable coarser fraction. The material transported from the upstream zone may fill in the flaw in the core, if retained effectively at the filter face adjacent to the core.

In this study, the Crack-Filling Erosion Test 
(CFET), developed entirely at Laboratório Nacional de Engenharia Civil (LNEC), was used. An innovative aspect of the CFET is the ability to test specimens comprising three distinct zones, which enables the modelling the upstream zone, the core and the downstream filter.

A short explanation of the CFET is presented in the next section. The main characteristics of the upstream soils, cores and downstream filters used are described. Then, the testing conditions are detailed, and the test results are presented and analysed. The parameters of the soils found to be critical for the occurrence or not of the crack-filling action are identified. Finally, some practical rules, for preliminary estimation of the likelihood of crack-filling action being effective stopping progression of internal erosion in concentrated leaks, are indicated.

\section{CFET SETUP}

The CFET setup is illustrated in Figure 1. A core, an upstream material and a downstream filter are compacted sequentially (in that order) inside a cylindrical mould (inner diameter of $280 \mathrm{~mm}$ ). Prior to compaction of the upstream soil, a hole is pre-drilled in the centre of the core (diameter of 12 or $16 \mathrm{~mm}$ ) to model the flaw causing the concentrated leak. An acrylic glass cover plate allows direct observation of the downstream filter face. Two concentric springs and a plate (with a hole in the centre) are placed in the upstream chamber to provide some lateral support to the upstream material.

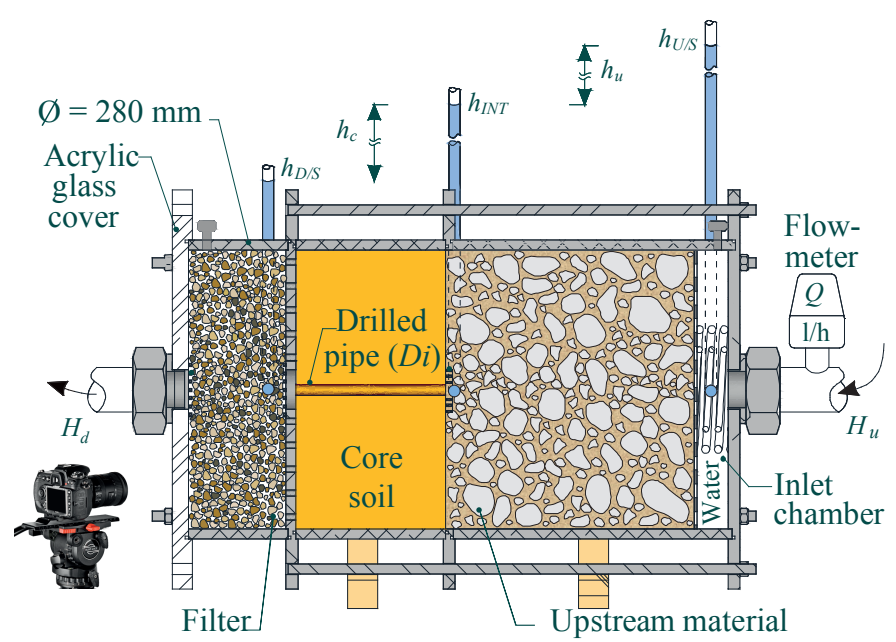

Figure 1: CFET setup

During a test, the specimen is subjected to water flow imposed through a constant hydraulic head loss, $\Delta H=H_{u}-H_{d} . H_{u}$ and $H_{d}$ are the total head at the entrance and exit of the test cell, respectively. During the tests, measurements of piezometric heads and flow rates are made, and visual observations through the downstream acrylic glass cover plate are carried out. Piezometric heads are measured, at the pipe level, using plastic tubes immediately upstream of the specimen, $h_{U / S}$, near the upstream-core interface, $h_{I N T}$, and inside the downstream filter, $h_{D / S} \cdot h_{u}=h_{U / S}-$ $h_{I N T}$, and $h_{c f}=h_{I N T}-h_{D / S}$ are the piezometric head losses along the upstream material, and along the core and core-filter interface, respectively. The flow rate, $Q$, is measured by a flow meter placed upstream of the test cell.

The deposition of eroded material in the filter face in contact with the acrylic glass and the turbidity of the effluent are recorded with a digital camera and sent to a laptop. To evaluate the erosion loss in the gap-graded upstream materials, particle-size distribution analysis of samples taken from different zones is also performed. The quantification of the amount of retained particles, in the tests in which a notable entrainment of material into the filter is observed, is also carried out. This is performed by considering the weight difference in relation to the initial filter weight.

More details about the test cell, the specimen preparation, the test set-up, and the test procedures are presented in Correia dos Santos et al. (2015a, 2015b).

\section{MATERIALS TESTED}

Figure 2 and Figure 3 show the gradation curves of the soils used in the laboratory tests as upstream material, and as core and downstream filter, respectively.

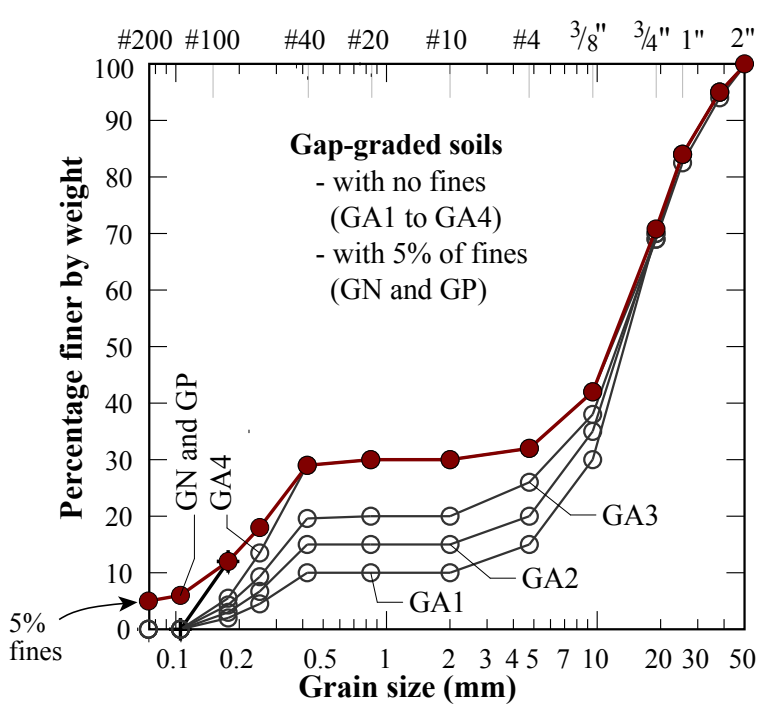

Figure 2: Grain-size distribution curves of upstream soils

Table 1 presents the main properties of the soils used in the CFET as the core. It includes information on the classification and compaction parameters of the soils. In addition, the conceptual filter erosion boundaries defined by Foster \& Fell (2001) for $D_{15 F}$ are also indicated (plotted in Fig. 3).

Table 2 presents the main properties of the gapgraded soils used as the upstream material and as the downstream filter. The maximum and minimum dry unit weights of the soils, obtained from standard density tests, are also presented.

The 4 gap-graded soils with no fines, with no medium-to-coarse sand, are formed by mixing soil A0 (soil used by Maranha das Neves (1989)) with a 


\begin{tabular}{lllllll}
\hline \multirow{2}{*}{ Core soils } & Soil classification system & \multicolumn{3}{l}{ Standard compaction tests } & \multicolumn{2}{l}{$\begin{array}{l}D_{15 F}(\mathrm{~mm}) \text { from Foster \& Fell (2001) } \\
\text { conceptual filter erosion boundaries }\end{array}$} \\
\cline { 3 - 7 } & & $\begin{array}{l}w_{\text {opt }} \\
(\%)\end{array}$ & $\begin{array}{l}\gamma_{d, \max } \\
\left(\mathrm{kN} / \mathrm{m}^{3}\right)\end{array}$ & $\begin{array}{l}\text { No erosion } \\
\text { boundary }\end{array}$ & $\begin{array}{l}\text { Excessive erosion } \\
\text { boundary }\end{array}$ & $\begin{array}{l}\text { Continuing erosion } \\
\text { boundary }\end{array}$ \\
\hline Core\#4 & SC - Clayey sand & 14.4 & 19.0 & 1.9 & 2.3 & 36.0 \\
Core\#20 & CL - Sandy lean clay & 17.2 & 17.8 & 0.7 & 5.0 & 6.3 \\
\hline
\end{tabular}

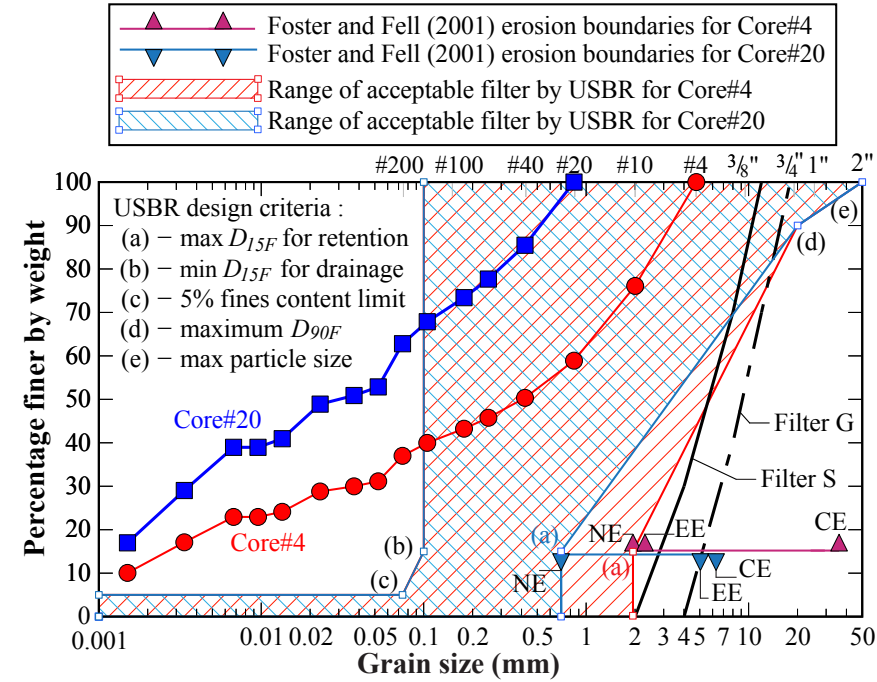

Figure 3: Grain-size distribution curves of core and filter soils

Table 2: Properties of upstream soils and filters

\begin{tabular}{|c|c|c|c|c|c|c|c|}
\hline \multirow[b]{2}{*}{ Soils } & \multirow[b]{2}{*}{$\begin{array}{l}w_{L} \\
(\%)\end{array}$} & \multirow[b]{2}{*}{$\begin{array}{l}I_{p} \\
(\%)\end{array}$} & \multirow[b]{2}{*}{$C_{u}$} & \multirow[b]{2}{*}{$C_{c}$} & \multirow[b]{2}{*}{$\begin{array}{l}\text { Soil } \\
\text { class. }\end{array}$} & \multicolumn{2}{|c|}{ Density tests } \\
\hline & & & & & & $\begin{array}{l}\gamma_{d, \min } \\
k N / m^{3}\end{array}$ & $\begin{array}{l}\gamma_{d, \max } \\
k N / m^{3}\end{array}$ \\
\hline \multicolumn{8}{|c|}{ Upstream soils } \\
\hline GA1 & - & - & 8.6 & 2.6 & GW & 15.2 & 18.1 \\
\hline GA2 & - & - & 59 & 14 & GP & 16.6 & 18.7 \\
\hline GA3 & - & - & 66 & 10 & GP & 17.3 & 19.6 \\
\hline GA4 & - & - & 69 & 0.4 & GP & 17.6 & 20.0 \\
\hline GN & NP & NP & 90 & 0.3 & GP-GM & 17.7 & 20.2 \\
\hline GP & 38 & 14 & 90 & 0.3 & GP-GC & 17.6 & 20.1 \\
\hline \multicolumn{8}{|c|}{ Filters } \\
\hline S & - & - & 2.6 & 0.5 & GP & 14.5 & 16.9 \\
\hline G & - & - & 1.4 & 0.8 & GP & 14.4 & 16.4 \\
\hline
\end{tabular}

variable soil fraction coarser than No. 10 sieve. Soils GA1, GA2, GA3 and GA4 are mixtures containing a content of fine sand (soil A0), $p A 0$, respectively, 10, 15,20 and $30 \%$. The soil fraction coarser than the No. 10 sieve is made mainly of fine-to-coarse gravel, with some coarse sand. The Two gap-graded soils with 5\% of fines are obtained by mixing $25 \%$ of soil A0, a fraction coarser than No.10 sieve and 5\% of non-plastic or plastic fines, resulting in Soils GN or GP, respectively.

Fig. 3 shows the acceptable range for the filters, according to current USBR (2011) criteria for core soils used. Excessively coarse filters were intentionally selected to violate the USBR retention criterion of no erosion of either Core\#4 or Core\#20 (i.e., they fail to meet Criterion (a) shown in Fig. 3).
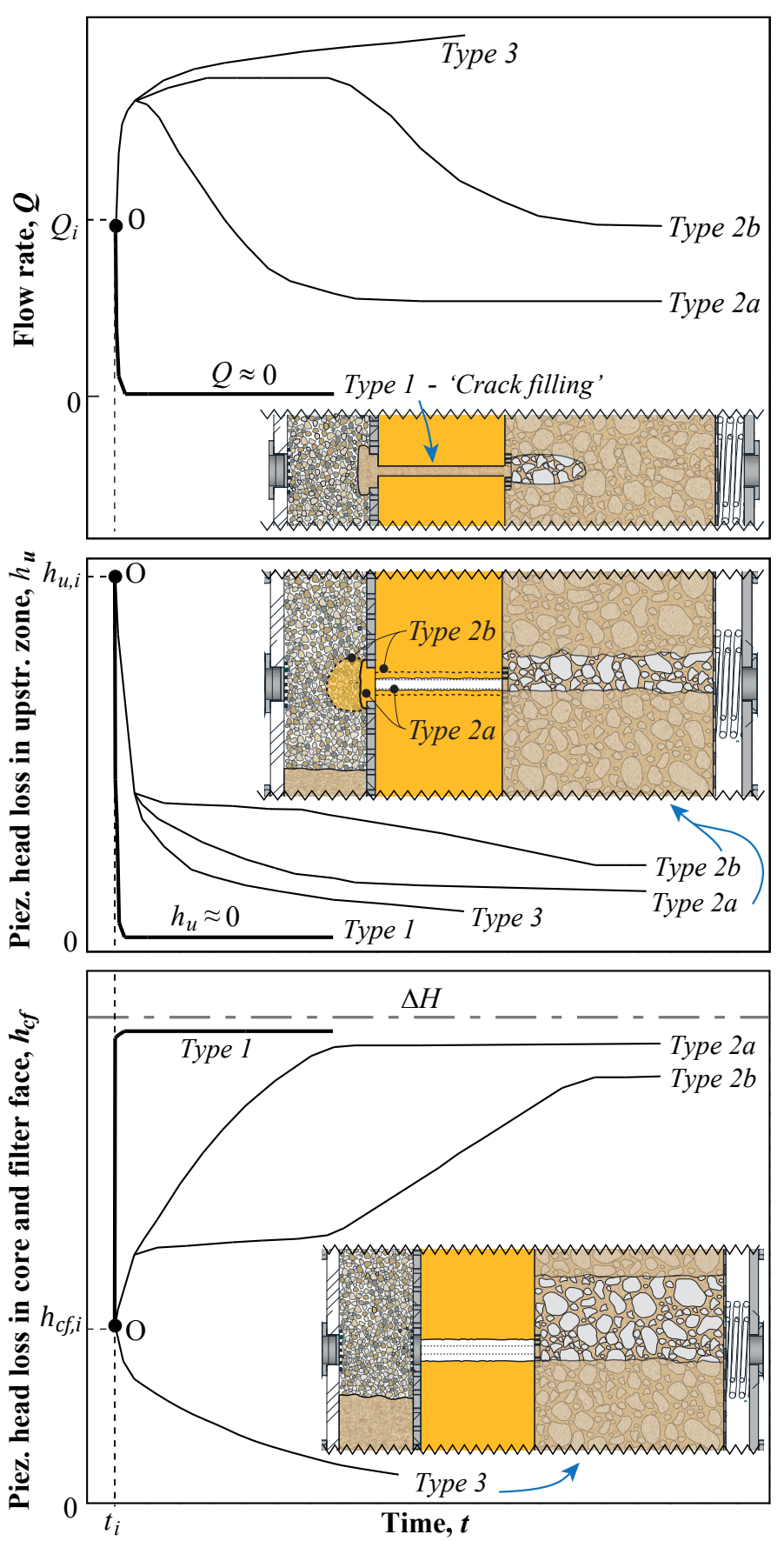

Figure 4: Behaviour types observed in the CFETs

With regard to the conceptual erosion boundaries of Foster \& Fell (2001), $D_{15 F}$ of Filter $S$ falls between the excessive and continuing erosion boundaries for Core\#4, and between the no erosion and the excessive erosion boundaries for Core\#20. Thus, Filter S is expected to seal after "excessive" erosion of Core\#4 and "some" erosion of Core\#20. Filter G is expected 
to seal after "excessive" erosion of both Core soils.

\section{BEHAVIOUR TYPES OBSERVED IN PERFORMED CFETS}

The CFET allowed to identify three main types of behaviours: rapid "pipe-filling" with "no erosion" of the core (Type 1); filtering after "some erosion" (Type $2 a$ ) or after "excessive erosion" (Type $2 b$ ) of the core and/or upstream material; and "continuing erosion" of the core and upstream material (Type 3). Figure 4 shows the trend of the flow rate, $Q$, and piezometric head losses $h_{u}$ and $h_{c f}$, for each behaviour type, and illustrates the typical layout of the specimen at the end of the tests.

The tests showing behaviour Type 1 are characterised by an extremely rapid transport of a considerable amount of particles of the upstream material at the interface with the core. The washed-in particles travel along the pipe in the core (forming a "sand jet") up to the downstream filter face. The filter retains the front of the "sand jet", which in turn fills in the pipe, stopping the erosion process.

In tests showing Type $2 a$ or Type $2 b$, the flow rate starts increasing fast, mainly due to the development of suffusion in the upstream material. The data indicate that the downstream filter is unable to retain the material coming from the upstream material. At a given instant, the hydraulic shear stresses, applied to the inner surface of the pipe in the core, reach values high enough to start detaching the sand-size particles, which are then retained at the downstream filter face.

In Type $2 a$, at some point, a trend toward decreased flow rate is observed, though at a progressively slower rate. The data suggest that the occurrence of a progressive filtering mechanism. In Type $2 b$ the filter is less effective than in Type $2 a$, sealing only after the detachment of an excessive amount of soil from the pipe. The eroded particles from the core are transported by flow up to the filter face, and, then, slowly seep into the filter. This leads to two opposite effects on the flow rate. On the one hand, the widening of the pipe diameter tends to increase the flow, and, on the other hand, the decrease of the filter permeability hinders seepage flow. This balance may result in an increase or stabilisation of the flow rate for a period, which, then, at some point, starts to decrease, until a new equilibrium is reached.

In tests showing Type 3, the flow rate increases fast. This indicates a rapid progression of suffusion in the upstream material, and that the filter is too coarse to retain those particles. Thereafter, the increase of the flow rate is mostly because of the enlargement of the pipe in the core, and thus is slower than previously.

Figures 5 and 6 show some photos of CFETs showing Type 1 - rapid crack-filling action (in a test using the PVC tube) and Type 3 - Continuing erosion (i,e, no crack-filling action), respectively. Photos of
CFETs showing Types $2 a / 2 b$ are presented in Correia dos Santos et al. (2015a).

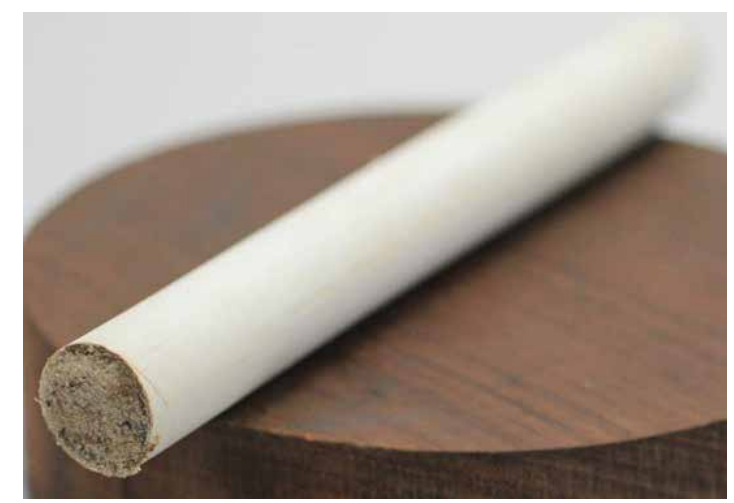

(a) PVC filled with soil from uptream soil

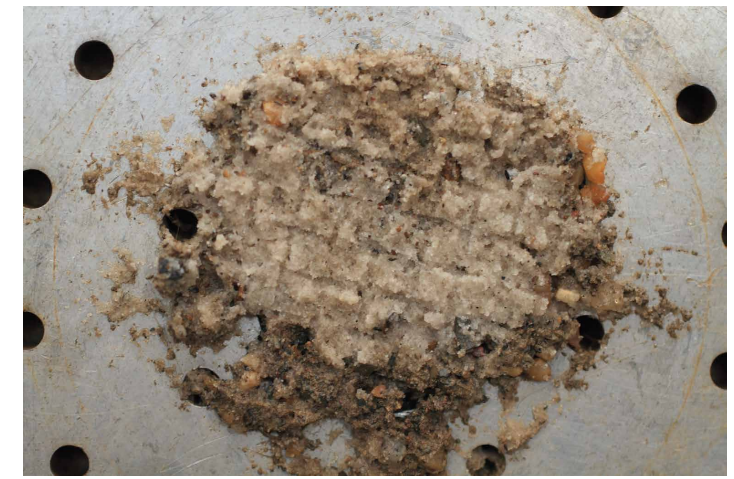

(b) Interface Core/Filter (Core face)

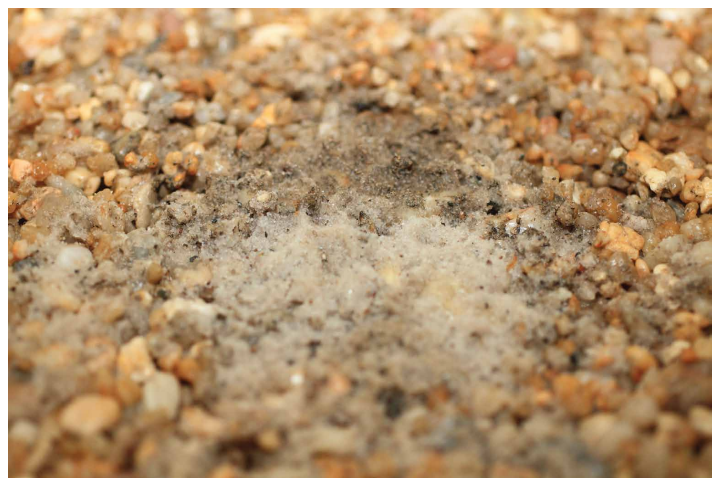

(c) Interface Core/Filter (Filter face)

Figure 5: Photos after cell dismounting in CFET with PCV tube in Core resulting in crack-filling action (Type 1)

\section{TEST CONDITIONS EXAMINED}

\subsection{Common characteristic of tests}

In all the CFETs performed, the conservative approach of preparing the filter to a relative density, $D_{r}$, somewhat smaller than $70 \%$, was considered. Some standards (e.g. USBR (2011)) consider this value as the minimum $D_{r}$, for filters in dams, in particular, in high seismic zones where liquefaction is a concern.

\subsection{Preliminary CFETs using a PVC tube in the core}

In the first CFETs performed, a plastic (PVC) tube was inserted in the centre of the core along its length to model the preformed hole. These tests aimed at 


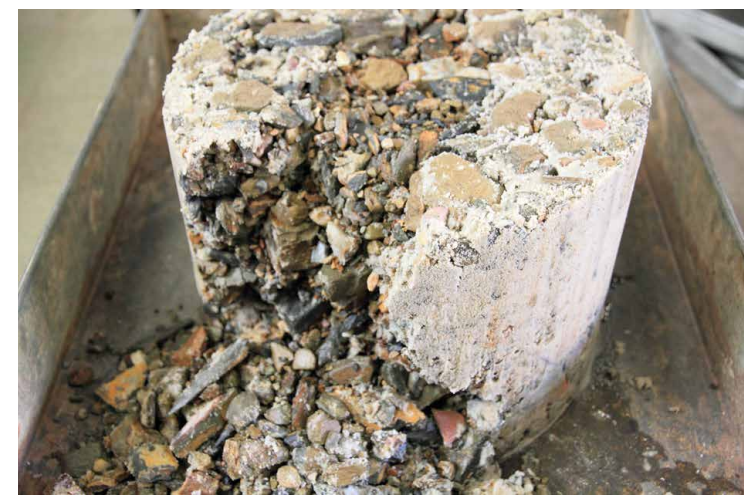

(a) Upstream material

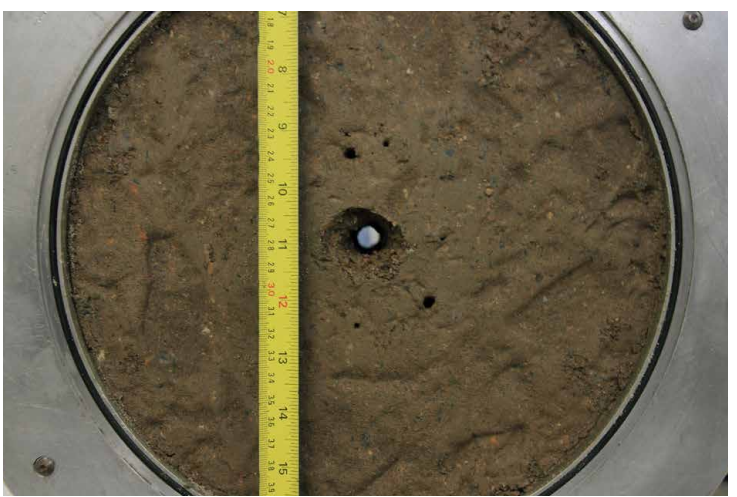

(b) Core

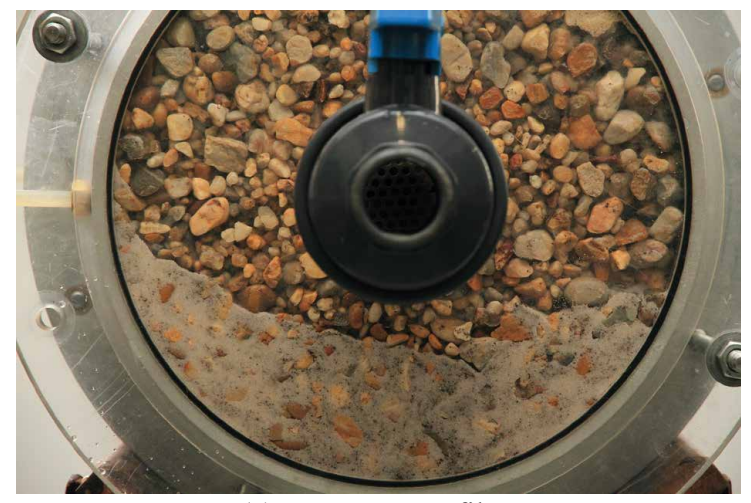

(c) Downstream filter

Figure 6: Photos after cell dismounting in CFET resulting in NO crack-filling action (Type 3)

the preliminary assessment of the ability of the gapgraded mixtures to fill in the tube caused by a rapid initiation of suffusion. The use of the plastic tube is a simple way to evaluate the compatibility between the filter and the soil eroded from the upstream material, disregarding the eventual filtering mechanism caused by the eroded particles detached from the core. If the rapid crack-filling action occurs in a test using the plastic tube, predictably, it is expected to occur in a test under the same conditions, but where the flow is forced to pass through a hole drilled in a core that is not excessively erodible. Otherwise, one cannot attribute a particular behaviour type, since it should depend on the erodibility of the core, and on the compatibility between the eroded soil and the filter.

The installation of the plastic tube followed three main steps. First, the plastic tube was cut to the length of the core. Second, after compaction of the core, a hole was drilled along the centre of the soil. The diameter of the drill bit should be slightly smaller than the outer diameter of the plastic tube, but large enough to allow the tube to be inserted in the drilled hole. Third, to prevent parasitic flows between the tube and the core, and avoid slaking of the core, the soil surfaces around the tube ends were shaped with modelling clay.

Table 3 shows the conditions examined in sixteen CFETs performed with a plastic tube in the core, as well as the outcome of the tests. All the selected gapgraded soils were tested with each one of the filters ( $\mathrm{S}$ and $\mathrm{G}$ ), using the head loss $\Delta H=2.05 \mathrm{~m}$, and a plastic tube with $12 \mathrm{~mm}$ inner diameter (P12).

The CFETs GA3.S $S_{P 12}, G A 4 . S_{P 12}$ and $G A 4 . G_{P 12}$ resulted in the rapid filling of the tube (Type 1). Because of that, these three configurations of the soil specimen were also examined using a $16 \mathrm{~mm}$ diameter plastic tube (P16), but only CFET GA4.S $S_{P 16}$ exhibited behaviour Type 1 .

The gap-graded soils with $5 \%$ fines (Soils GN and GP) when tested against Filter $\mathrm{S}$ and with a $12 \mathrm{~mm}$ diameter plastic tube, that is, CFETs $G N . S_{P 12}$ and $G P . S_{P 12}$, also showed behaviour Type 1. After cell disassembly, however, a partial filling of the tube was noted, by contrast with the complete filling observed in the CFETs on the soils GA3 and GA4 showing behaviour Type 1. The tube was filled to about half of its length and up to a few centimetres (20 to $30 \mathrm{~mm}$ ) in the test on Soil GN (with non-plastic fines) and on soil GP (with fines of some plasticity), respectively.

\subsection{CFETs on gap-graded soils with a hole pre-drilled in the core soil}

Table 3 shows the conditions examined in eighteen CFETs on gap-graded soils, in which the flow is forced to pass through a $12 \mathrm{~mm}$ diameter hole drilled in the core (D12), as well as the outcome of the tests. The hydraulic head loss in these tests is the same as that in the tests using the plastic tube.

Sixteen CFETs used Core\#4. Each gap-graded soil was examined in the test cell without any downstream filter (e.g. $G A 3_{D 12}$ ). By comparing the results of these tests with the CFETs performed under similar conditions, but in which a filter layer is used, one can evaluate the single contribution of the filter in the evolution of the flow rate. The remaining ten tests were conducted with either Filter S or Filter G. It is noted, however, that these tests do not cover all the upstream material - filter specimen layouts tested using the plastic tube. The findings of the CFETs using the PVC tube, allowed to excluded test conditions that certainly would not result in crack-filling action, or in a substantially different behaviour compared to the analogous test with the plastic tube.

Two CFETs used Core\#20 (finer than Core\#4). CFETs GA2.S.C\#20 $D 12$ and GA3.G.C\#20 $D 12$ were performed to evaluate the progression of erosion in test conditions in which the downstream filter is expected to be unable to effectively retain the particles detached from the pipe in the core. The specimens 


\begin{tabular}{|c|c|c|c|c|c|c|}
\hline \multirow[b]{2}{*}{ CFET no. } & \multirow{2}{*}{$\begin{array}{l}\text { PVC tube } \\
D_{i}(\mathrm{~mm})\end{array}$} & \multicolumn{2}{|c|}{ Upstream Soil } & \multirow[b]{2}{*}{ Filter } & \multirow[b]{2}{*}{ Test duration (minutes) } & \multirow[b]{2}{*}{ Behaviour type } \\
\hline & & Type & Density (\%) & & & \\
\hline$G A 1 . S_{P 12}$ & 12 & GA1 & 117.2 & $\mathrm{~S}$ & 40 & NA \\
\hline$G A 1 . G_{P 12}$ & 12 & & 116.4 & G & 45 & Not applicable \\
\hline$G A 2 . S_{P 12}$ & 12 & GA2 & 124.7 & $\mathrm{~S}$ & 50 & NA \\
\hline$G A 2 . G_{P 12}$ & 12 & & 124.7 & $\mathrm{G}$ & 45 & Not applicable \\
\hline$G A 3 . S_{P 12}$ & 12 & GA3 & 88.1 & $\mathrm{~S}$ & 30 & Type 1 \\
\hline$G A 3 . S_{P 16}$ & 16 & & 88.1 & $\mathrm{~S}$ & 60 & Not applicable \\
\hline$G A 3 . G_{P 12}$ & 12 & & 85.0 & $\mathrm{G}$ & 50 & Not applicable \\
\hline$G A 3 . G_{P 16}$ & 16 & & 91.1 & $\mathrm{G}$ & 45 & Not applicable \\
\hline$G A 4 . S_{P 12}$ & 12 & GA4 & 79.8 & $\mathrm{~S}$ & 30 & Type 1 \\
\hline$G A 4 . S_{P 16}$ & 16 & & 79.5 & $\mathrm{~S}$ & 30 & Type 1 \\
\hline$G A 4 . G_{P 12}$ & 12 & & 72.0 & G & 30 & Type 1 \\
\hline$G A 4 . G_{P 16}$ & 16 & & 70.4 & G & 45 & Not applicable \\
\hline$G N . S_{P 12}$ & 12 & GN & 79.9 & $\mathrm{~S}$ & 30 & Type 1 (Partial filling) \\
\hline$G N \cdot G_{P 12}$ & 12 & & 70.1 & $\mathrm{G}$ & 45 & Not applicable \\
\hline$G P . S_{P 12}$ & 12 & GP & 70.1 & $\mathrm{~S}$ & 30 & Type 1 (Partial filling) \\
\hline$G P . G_{P 12}$ & 12 & & 70.1 & G & 45 & Not applicable \\
\hline
\end{tabular}

Table 4: Conditions examined in each CFET on gap-graded soils with a hole drilled in the core, and test results

\begin{tabular}{|c|c|c|c|c|c|c|c|c|c|c|}
\hline \multirow[b]{3}{*}{ CFET no. } & \multicolumn{7}{|c|}{ Test specimen characteristics } & \multirow[b]{3}{*}{$\begin{array}{l}\text { Duration } \\
\text { (min.) }\end{array}$} & & \\
\hline & \multicolumn{3}{|c|}{ Core $\left(D_{i}=12 \mathrm{~mm}\right)$} & \multicolumn{2}{|c|}{ Upstream material } & \multicolumn{2}{|l|}{ Filter } & & \multicolumn{2}{|c|}{ Test results } \\
\hline & Type & $\begin{array}{l}w-w_{o p t} \\
(\%)\end{array}$ & $\begin{array}{l}\gamma_{d} / \gamma_{d, \max } \\
(\%)\end{array}$ & Type & $D_{r}(\%)$ & Type & $\begin{array}{l}D_{r} \\
(\%)\end{array}$ & & $\begin{array}{l}D_{f} \\
(\mathrm{~mm})\end{array}$ & Behaviour \\
\hline$G A 1_{D 12}$ & Core\#4 & 0 & 94.2 & GA1 & 110 & - & - & 67 & 24 & Type 3 \\
\hline$G A 1 . S_{D 12}$ & & -0.2 & 94.1 & & 116.7 & $\mathrm{~S}$ & 56.9 & 60 & 15 & Type $2 a$ \\
\hline$G A 2_{D 12}$ & & -0.3 & 94.7 & GA2 & 105 & - & - & 60 & 24 & Type 3 \\
\hline$G A 2 . S_{D 12}$ & & -0.5 & 94.9 & & 132.2 & $\mathrm{~S}$ & 58.2 & 60 & 17 & Type $2 a$ \\
\hline$G A 2 . G_{D 12}$ & & -0.2 & 94.9 & & 81.8 & $\mathrm{G}$ & 67.6 & 60 & 18 & Type $2 a$ \\
\hline$G A 3_{D 12}$ & & 0.1 & 95.2 & GA3 & 102.0 & - & - & 60 & 25 & Type 3 \\
\hline$G A 3 . S_{D 12}$ & & 1.5 & 95.6 & & 107.4 & $\mathrm{~S}$ & 64.2 & 30 & $*$ & Type 1 \\
\hline$G A 3 . G_{D 12}$ & & -0.1 & 94.1 & & 107.6 & G & 67.6 & 50 & 18 & Type $2 a$ \\
\hline$G A 4_{D 12}$ & & -0.4 & 94.8 & GA4 & 99 & - & - & 60 & 29 & Type 3 \\
\hline$G A 4 . G_{D 12}$ & & -0.2 & 94.6 & & 76.3 & G & 67.6 & 30 & $*$ & Type 1 \\
\hline$G N_{D 12}$ & & -0.5 & 95.4 & GN & 98.0 & - & - & 15 & 30 & Type 3 \\
\hline$G N . S_{D 12}$ & & -0.1 & 94.5 & & 97.6 & $\mathrm{~S}$ & 53.3 & 58 & $*$ & Type $1(P F)$ \\
\hline$G N \cdot G_{D 12}$ & & 0 & 94.2 & & 97.7 & G & 67.6 & 75 & 16 & Type $2 a$ \\
\hline$G P_{D 12}$ & & -0.5 & 96.9 & GP & 96 & - & - & 45 & 30 & Type 3 \\
\hline$G P . S_{D 12}$ & & 0.1 & 94.3 & & 101.1 & $S$ & 53.3 & 29 & $*$ & Type $1(P F)$ \\
\hline$G P . G_{D 12}$ & & 0.3 & 94.1 & & 77.2 & G & 67.6 & 50 & 18 & Type $2 a$ \\
\hline GA2.S.C\#20 ${ }_{D 12}$ & Core\#20 & 2.3 & 94.2 & GA2 & 135.9 & $\mathrm{~S}$ & 56.9 & 105 & 45 & Type $2 b$ \\
\hline GA3.G.C\# $20_{D 12}$ & & 2.6 & 94.9 & GA3 & 95.7 & G & 67.6 & 30 & 29 & Type 3 \\
\hline
\end{tabular}

$G A 2 . S$ and $G A 3 . G$ were selected because the CFETs on these specimen layouts using Core\#4 did not result in the filling of the pipe, although a significant amount of fine sand eroded from the upstream material has been washed into the filter.

Core\#4 was compacted near the optimum water content, $w_{o p t}$, and to a degree of compaction of $95 \%$, in relation to the standard (Proctor) compaction test. For these compaction properties, Core\#4 shows an erosion rate index in the Hole Erosion Test (Wan \& Fell 2004), $I_{H E T}$, around 4.1, which corresponds to a moderate soil erosion behaviour (Correia dos Santos et al. 2012). This soil erodibility condition was selected to avoid possible overlapping of the influence of the upstream material by an excessively high or low core erosion rate.

Core\#20 was prepared wetter, at $w_{\text {opt }}+2.5 \%$ and to $=95 \%$, in relation to standard compaction tests. For these compaction properties, Core\#20 showed moderate erosion behaviour in the HET $\left(I_{H E T}\right.$ slightly above 4) (Correia dos Santos et al. 2012).

The CFETs GA3.S $S_{D 12}, G A 4 . G_{D 12}, G N . S_{D 12}$ and 
$G P . S_{D 12}$ behaved as the analogous tests with the $12 \mathrm{~mm}$ diameter plastic tube (P12), that is, they showed behaviour Type 1 ("crack-filling" action). This is an indication that the occurrence of rapid crack-filling action is independent of the characteristics of the core, provided that the core is not excessively erodible. This means that, in such cases, the compatibility of the particle sizes eroded from the upstream material and those of the filter, regarding the potential of the washed in material to be retained at the filter face and fill a considerable portion of the pipe length, can be simply evaluated in CFETs using a plastic tube to model the flaw in the core. These have the obvious advantage of allowing the reuse of the core specimen from test to test, which makes the specimen preparation less time-consuming.

\section{ANALYSIS OF THE TEST RESULTS}

The evolution of the flow rate, $Q$, and of the piezometric head losses along the upstream material, $h_{u}$, and along the core and the core-filter interface, $h_{c f}$, in the CFETs on soils without fines GA1 and GA2 is shown in Fig. 7, and on soils GA3 and GA4 in Fig. 8. Figure 9 also shows $Q, h_{u}$ and $h_{c f}$ but for the CFETs on soils GN and GP, with 5\% fines. In addition, these figures show the flow rate recorded in the tests performed without any downstream filter. For reference, the CFETs showing Type 1 are indicated in a shaded box, whenever applicable.

\subsection{Tests without downstream filter}

None of the tests performed without a downstream filter showed Type 1, which is in agreement with the general idea that there is no possibility of crack-filling action when there is no filter. As a matter of fact, all of those tests showed behaviour Type 3 (illustrated in Fig. 4), that is, strong progression of erosion of the core and upstream material. A high permeability zone was always formed by suffusion in the centre and upper part of the upstream material along its entire length, together with an excessive enlargement of the pipe in the core. The final diameter of the pipe in the core, $D_{f}$, ranged from 24 to $25 \mathrm{~mm}$ in tests on soils GA1 to GA3, and from 29 to $30 \mathrm{~mm}$ on the soils GA4, GN and GP. Progression of erosion only slowed down when the maximum discharge capacity of the device was reached (around 0.5 litres/second).

\subsection{CFETs using a plastic tube}

In all these tests, during the initial instants, a trend toward increased flow, at a very fast rate, was recorded, which then stabilised, or increased very slowly. An initial rapid drop of $h_{u}$ and an increase of $h_{c f}$ were observed. Then, $h_{u}$ and $h_{c f}$ became practically constant after stabilisation of the flow rate.
Typically, the tests with a $16 \mathrm{~mm}$ diameter plastic tube (P16) and Filter G showed the highest flow rates. For a given upstream material and tube diameter, the maximum flow rate was higher in the test using Filter $\mathrm{G}$ than in the test with Filter $\mathrm{S}$. The deposition of eroded material at the bottom of the filter (due to gravity) was more notable in the tests with Filter G.

The dismounting of the cell revealed an empty and almost clean pipe, and the formation of a high permeability zone in the upstream material. The soil loss in the upstream material occurred along its entire length, mainly around the alignment of the pipe, and, in tests on gap-graded soils with no fines, also toward the top of the specimen.

The results of CFETs $G A 3 . S_{P 16}$ and $G A 4 . G_{P 16}$ suggest that they should had been close to reach behaviour Type 1 .

In the CFETs $G N . G_{P 12}$ and GP.G $G_{P 12}$, after stabilisation of $Q, h_{u}$ and $h_{c f}$ the values are practically the same in both tests. This means that the type of fines (non-plastic or plastic) had a minimal influence on the end result of the erosion process.

\subsection{CFETs using using Core\#4}

In all these CFETs the progressive filtering of the particles detached from the core led to a relevant limitation of the progression of the erosion process. They showed behaviour Type $2 a$ (illustrated in Fig. 4). Both the filters proved to be highly likely of sealing (with eroded particles from the upstream material) after "some" erosion of Core\#4, considering the conceptual boundaries indicated by Foster \& Fell (2001).

The suffusion in the upstream material occurred mainly along the centre of the specimen, seeming visually to be less notable than in the analogous tests using the plastic tube. A slurry material composed mainly of medium-to-coarse sand and fines of the core (and fines of Soils GN and GP) was retained at the filter face. It filled almost all the empty space at the core/filter interface (the hole in the centre of the perforated plate), thus restricting the flow.

The equivalent diameter of the pipe, $D_{f}$, was about $18 \mathrm{~mm}$ in the tests $G A 2 . G_{D 12}$ and $G A 3 . G_{D 12}$, and slightly smaller $(17 \mathrm{~mm})$ in the test $G A 2 . S_{D 12}$. The test $G A 1 . S_{D 12}$ showed an even smaller $D_{f}$ of about $15 \mathrm{~mm}$. In this test, the fall of the flow rate started sooner, and then stabilised at a higher value, when compared to the other tests on soils GA2 and GA3 (with no fines). In these tests $h_{c f}$ almost equalled the $\Delta H$, whereas in $G A 1 . S_{D 12}$ it was considerably smaller.

In regard to the tests on soils with $5 \%$ fines, GN and GP, $D_{f}$ was about $19 \mathrm{~mm}$ in test GN.G. $G_{D 12}$, and greater than the $16 \mathrm{~mm}$ in GP.G $G_{D 12}$. Also, flow stabilised at $0.16 \mathrm{l} / \mathrm{s}$ in $G N . G_{D 12}$, which is much greater than the $0.05 \mathrm{l} / \mathrm{s}$ in GP.G $G_{D 12}$. Moreover, in the test on soil GN, the slurry at the filter face showed fewer fines, and a greater amount of the soil loss in a larger 


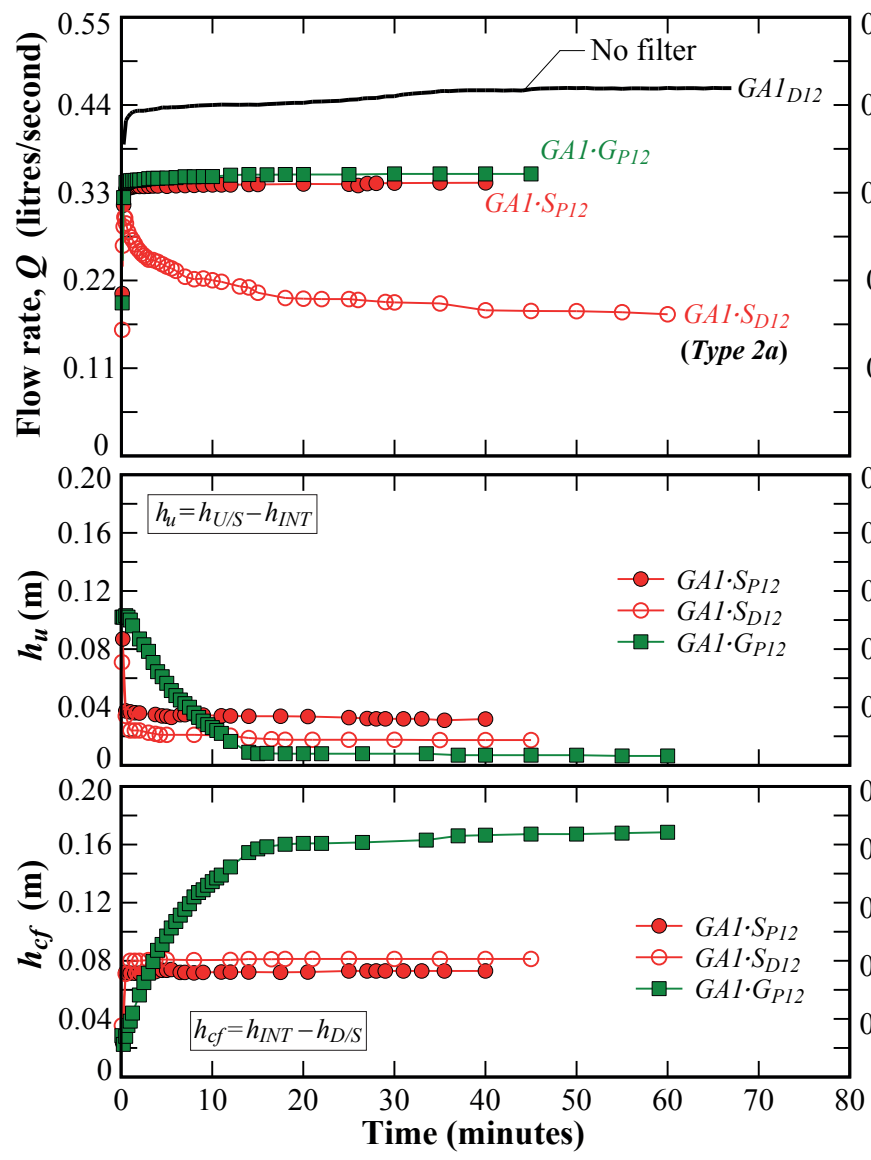

(a) CFETs on upstream soil GA1
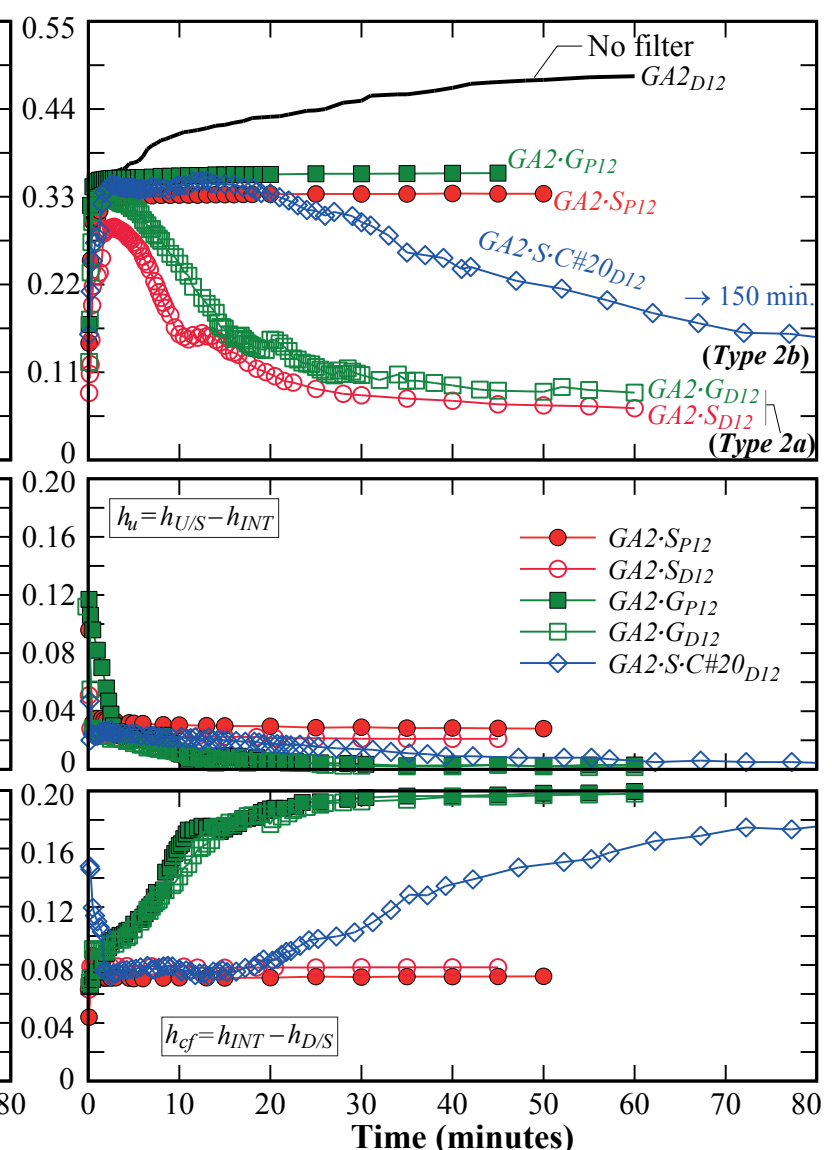

(b) CFETs on upstream soil GA2

Figure 7: Flow rate, $Q$, and piezometric head losses, $h_{u}$ and $h_{c f}$, in CFETs on Soils GA1 and GA2

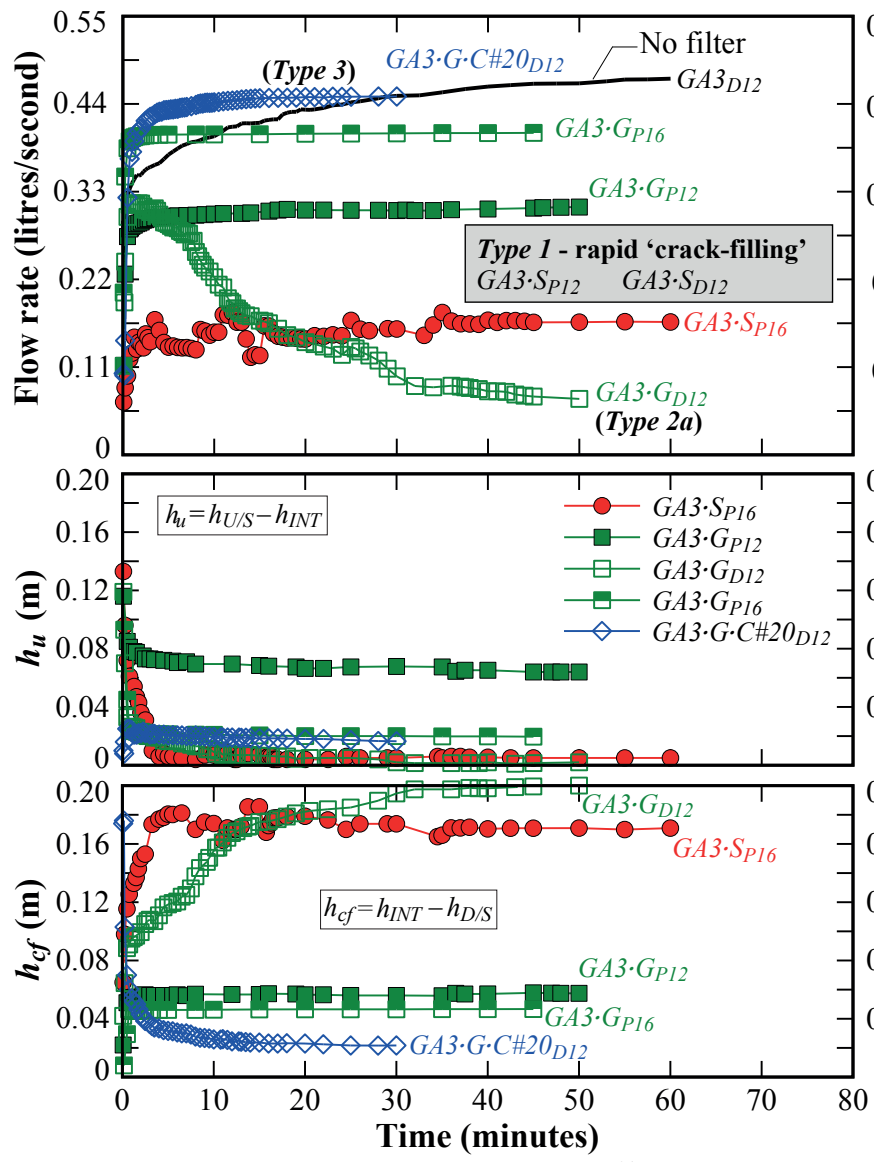

(a) CFETs on upstream soil $G A 3$
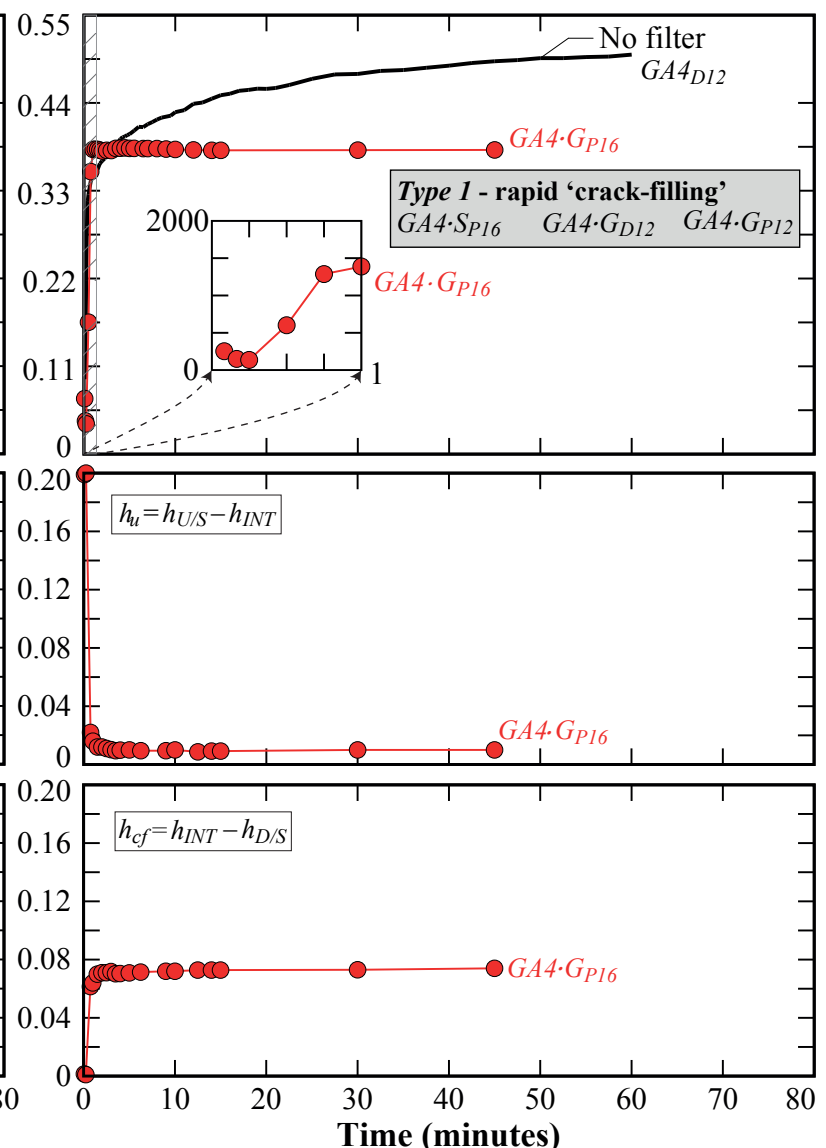

(b) CFETs on upstream soil GA4

Figure 8: Flow rate, $Q$, and piezometric head losses, $h_{u}$ and $h_{c f}$, in CFETs on Soils GA3 and GA4 


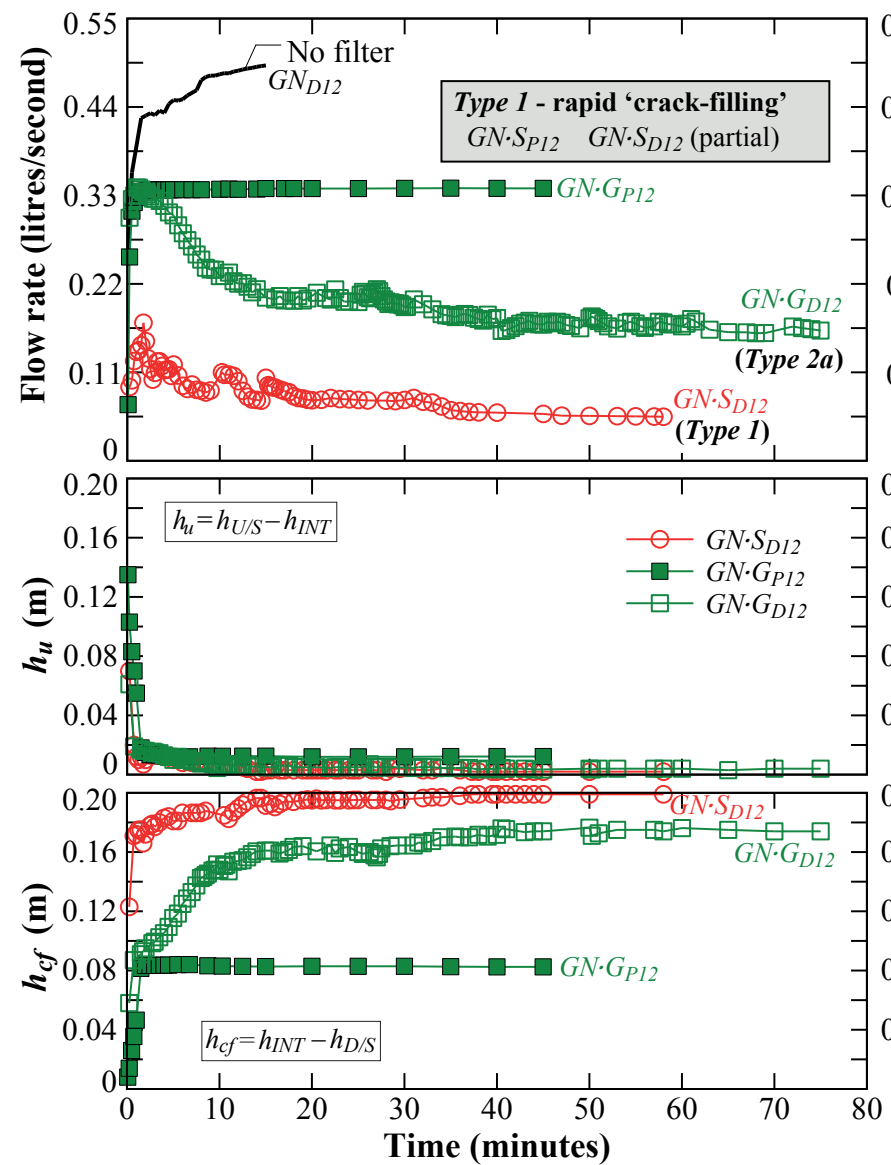

(a) CFETs on upstream soil GN

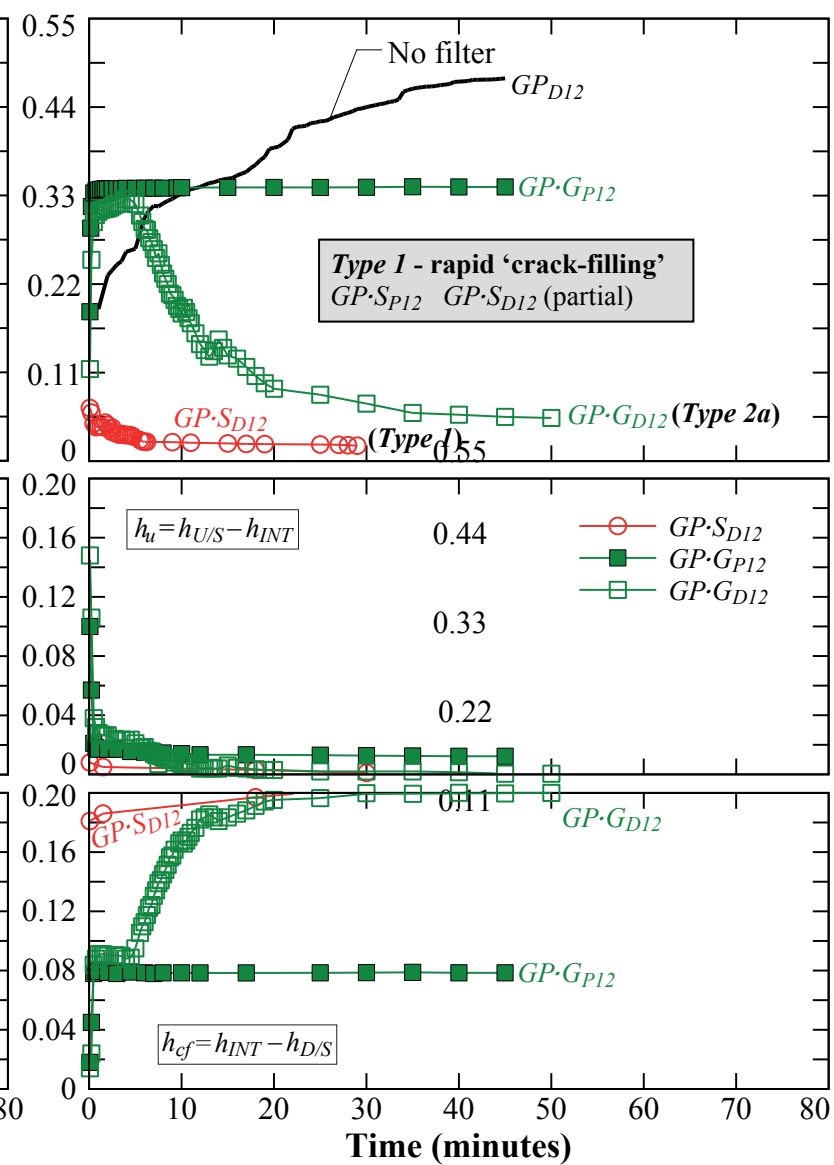

(b) CFETs on upstream soil GP

Figure 9: Flow rate, $Q$, and piezometric head losses, $h_{u}$ and $h_{c f}$, in CFETs on Soils GN and GP

area of erosion. All these are evidence that the type of plasticity of the fines of the upstream material has an influence on the filtering mechanism. The Filter $G$ sealed the eroded material from Soil GP (with fines of some plasticity) more efficiently than that from Soil GN (with non-plastic fines).

\subsection{CFETs using using Core\#20}

Upstream soil GA2 when tested against Filter S showed behaviour Type $2 b$, and upstream soil GA3 when tested against Filter G showed behaviour Type 3 . Core\#20 was found to be capable of sealing Filter $\mathrm{S}$, even after "excessive" erosion, and unable to seal Filter $\mathrm{G}$ in an effective manner, even after the initiation and progression of suffusion in the upstream soil.

The dismounting of the cell showed that the erosion pipe in the core was clear in both tests. Equivalent pipe diameters, $D_{f}$, of about $45 \mathrm{~mm}$ (after $105 \mathrm{~min}$ ) and $29 \mathrm{~mm}$ (after $30 \mathrm{~min}$ ) were estimated in GA2.S.C\#20 $0_{D 12}$ and GA3.G.C\#20 $20_{D 12}$, respectively. These are considerably larger than the 17-18 $\mathrm{mm}$ diameter observed in the analogous CFETs with Core\#4, which lasted about 50 minutes.

In GA2.S.C\#20 $0_{D 12}$, the initial empty space, between the exit of the pipe in the core and the filter face, was full of slurry material (fines and fine sand). Also, a relevant amount of fines and fine sand (silica and schist) was spread into the filter. This was more evident at the filter face adjacent to the core, particularly at the centre of the specimen. By contrast, in GA3.G.C\# $20_{D 12}$, the filter was relatively clean in the alignment of the pipe in the core. It was unable to retain the particles coming concurrently from the core and the upstream material, which ended up being deposited at the bottom of the filter.

In CFET GA2.S.C\#20 ${ }_{D 12}$, a high permeability zone formed in the upstream material because of suffusion. Post-test grain-size distribution analyses showed that erosion loss in the upstream material was greater than in the analogous test with Core\#4 (showing Type 2a). The variation of fine sand content content $p A 0$ in relation to initial Soil A0 content in soil mixture GA2, $\Delta p A 0 / p A 0$, in GA2.S.C\#20 $D 12$ was about $41 \%$, whereas in $G A 2 . S_{D 12}$ it was $27 \%$. This was accounted for by the larger erosion pipe in the core and the longer duration of the former test. When CFET GA2.S.C\#20 $D 12$ is compared against $G A 2 . S_{D 12}$, it is clear that the filter sealing in the former took about twice as long as the latter (100 versus 50 minutes), resulting in a substantially greater $D_{f}$ (45 versus $17 \mathrm{~mm}$ ).

Figure 10 shows the post-test grain-size distribution analyses performed on the upstream soil GA3 after CFETs GA3.G $G_{D 12}$ (with Core\#4) and GA3.G.C\#20 ${ }_{D 12}$ (with Core\#20).

In GA3.G.C\#20 $0_{D 12}$ a high permeability zone also formed in the upstream zone, but not only 

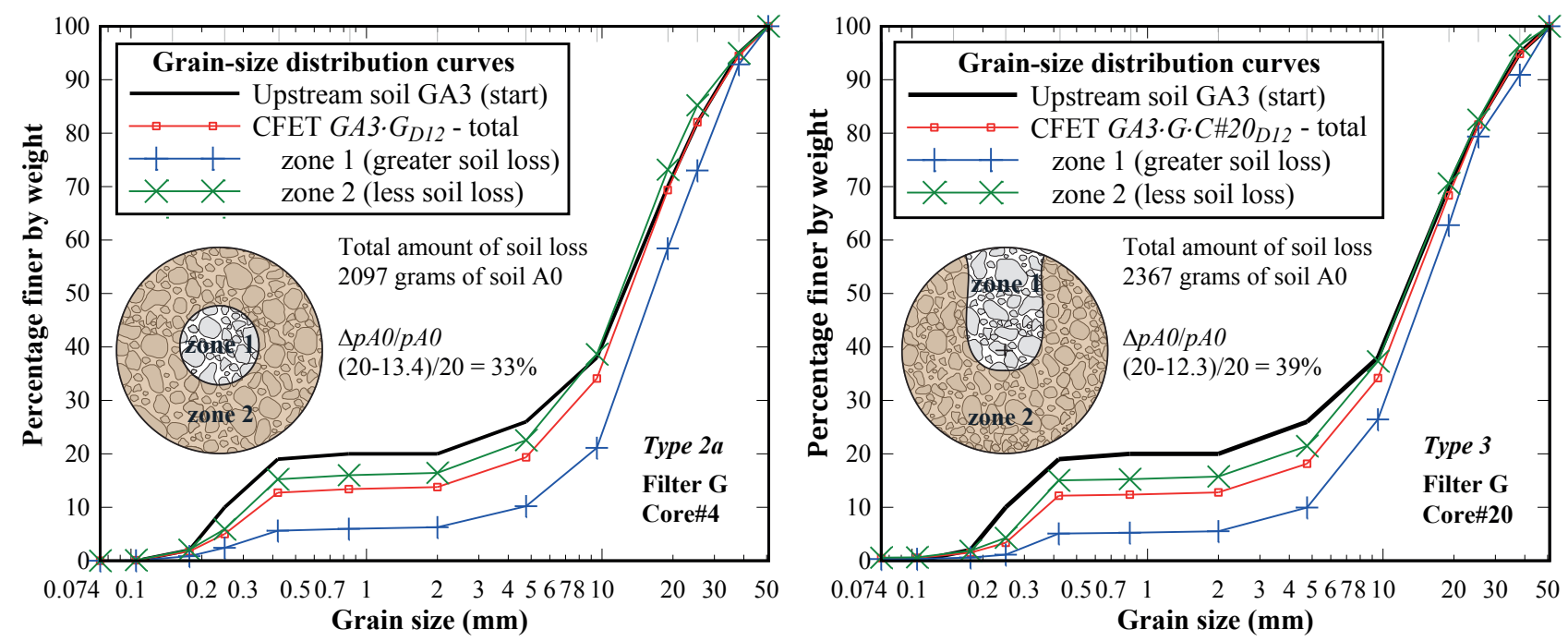

Figure 10: Evolution of grain-size distribution curves in CFETs GA3.G $G_{D 12}$ (at left) and GA3.G.C\#20 ${ }_{D 12}$ (at right)

around the alignment of the pipe in the core, as was noted for $G A 3 G_{D 12}$, but also above that zone. This was due to the effects of gravity and seepage on the particles of the fine fraction at the higher levels. In GA3.G.C\#20 $D 12, \Delta p A 0 / p A 0$ was about $39 \%$, which is greater than the $33 \%$ estimated in $G A 3 . G_{D 12}$, which lasted 20 minutes longer.

\section{PROPERTIES OF THE UPSTREAM SOIL INFLUENCING "CRACK FILLING"}

The key factors that are believed to influence the occurrence of the "crack-filling" action by the selected gap-graded soils in the CFET were classified into two main categories. The first category includes some of the parameters that define the initial grain-size distribution and plasticity of the fines of the upstream material. These are the fine sand content ( $p A 0)$, the fines content ( $p f 200)$ and the type of the plasticity of the fines (i.e. non-plastic or plastic), and the gravel content $(p c 4)$.

The second category is associated with the compatibility between the particles sizes of the material eroded from the upstream zone and the filter. This is evaluated considering the conceptual filter erosion boundaries, and by checking the relation between $p A 0$ of the upstream soil and $D_{15 F}$ of the filter.

\subsection{Influence of grain-size distribution and type of plasticity of the fines}

Figure 11 shows the behaviour type observed in each CFET on the selected upstream soils against the fine sand content, $p A 0$, and the gravel content, $p c 4$.

In CFETs with $D_{i}=12 \mathrm{~mm}$, Type 1 occurred in tests with Filter $\mathrm{S}$ together with upstream soil mixtures of $p A 020 \%$ and $p c 4$ 74\% (Soils GA3, GA4, GN and GP), and in tests using Filter $\mathrm{G}$ together with soils of $p A 030 \%$ and $p c 4 \quad 68 \%$ (GA4).

As regards tests with $D_{i}=16 \mathrm{~mm}$, Type 1 was observed in a test where the Filter $\mathrm{S}$ was used together with the upstream gap-graded soil GA4, which has $p c 4$ of $68 \%$ and the highest $p A 0$ (equal to $30 \%$ ) of all the gap-graded soils tested. This is a clear indication that the size of the flaw in the core is a relevant parameter for the occurrence of the crack-filling action. These results suggest that, for the same upstream gapgraded material and filter, the higher the diameter of the pipe the less likely pipe filling is in the CFET.

Gap-graded soils GN and GP, with $p f 200=5 \%$ and $p A 0=25 \%$, showed limited effectiveness at filling in the pipe in the core, given that behaviour Type 1 occurred only in tests using Filter S. In addition, in such tests, the filling of the pipe in the core took a little longer and was only partial, unlike the complete pipe filling seen in tests on other soils with behaviour Type 1. This suggests that fine content higher than 5\% may inhibit crack filling, even if the fines are non-plastic, but especially when they are plastic.

Figure 12 shows the relation between the content of fine sand in the upstream material, $p A 0$, against the equivalent diameter $D_{15 F}$ of the filter, at the start of each CFET on the uniform and gap-graded soils performed with a pipe in the core of $D_{i}=12 \mathrm{~mm}$. The CFETs in which Type 1 (rapid "crack-filling" action) was observed are highlighted with a hollow circle symbol.

\subsection{Compatibility between the upstream material and the filter}

From Figure 12 it can be concluded that for $D_{15 F}$ around $2.9 \mathrm{~mm}$ (Filter $\mathrm{S}$ ), the filling of the pipe in the core occurred for $p A 0$ equal to or above $20 \%$. For $D_{15 F}$ around $5.1 \mathrm{~mm}$ (Filter $\mathrm{G}$ ), the pipe filled only for $p A 0$ equal to or above $30 \%$ (soil GA4).

For a given pipe size in the core, the lower the $D_{15 F}$ and the higher the $p A 0$ of the upstream soil, the higher should be the likelihood of "crack-filling" action occurring. Type 1 is expected in CFETs (with $D_{i}=12$ $\mathrm{mm}$ ) on specimens that plot below a certain boundary curve, represented schematically with the dashed 

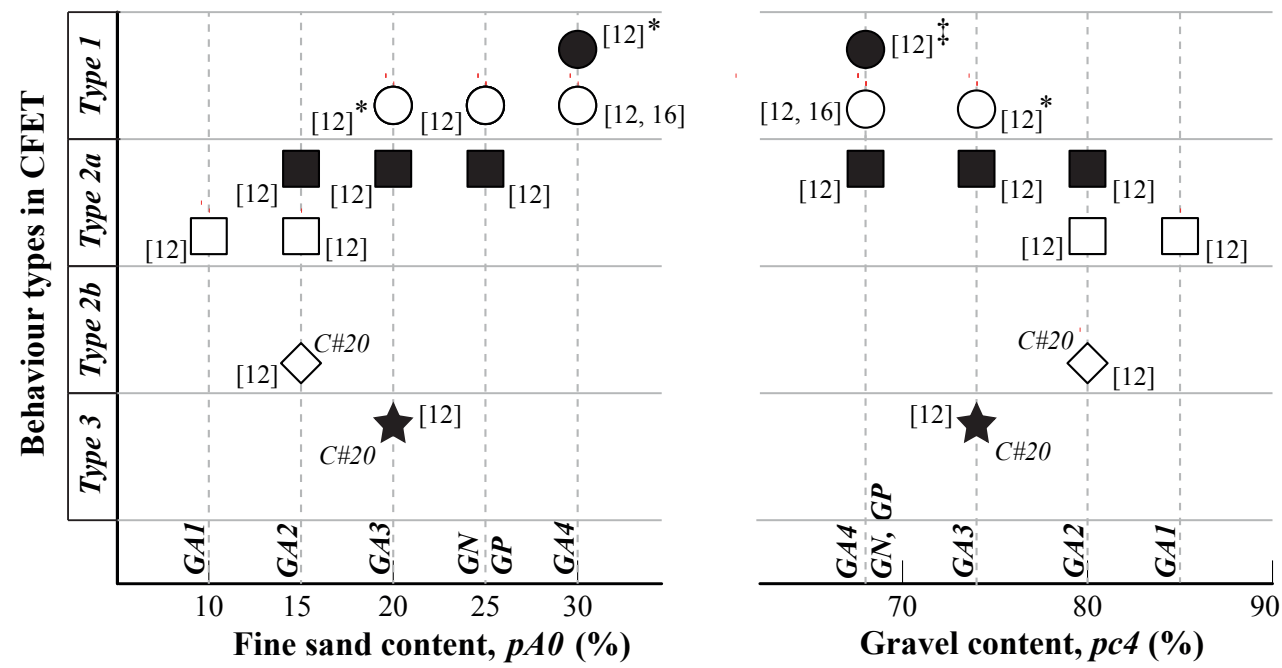

\begin{tabular}{|c|}
\hline $\begin{array}{l}\text { Filter } G \leftrightarrow \text { Solid symbols } \\
\text { Filter } S \leftrightarrow \text { Hollow symbols }\end{array}$ \\
\hline $\begin{array}{l}\text { Values inside brackets are } \\
\text { the tested pipe diameters } \\
\text { (e.g., } D_{i}=12 \mathrm{~mm} \leftrightarrow[12] \text { ) }\end{array}$ \\
\hline Test with Core\#20 $\leftrightarrow C \# 20$ \\
\hline $\begin{array}{r}* \text { Soil with } D_{i}=16 \mathrm{~mm} \text { did not } \\
\text { showed Type } 1 \\
\text { *GA4 with } D_{i}=\begin{aligned} 16 \mathrm{~mm} \text { did not } \\
\text { show Type } 1\end{aligned}\end{array}$ \\
\hline Behaviour types \\
\hline $\begin{array}{l}\text { Type } 1 \text { - rapid 'crack-filling' } \\
\text { Type } 2 a \text { - filtering after } \\
\text { 'some erosion' } \\
\text { Type } 2 b \text { - filtering after } \\
\text { 'excessive erosion' } \\
\text { Type } 3 \text { - 'continuing erosion' }\end{array}$ \\
\hline
\end{tabular}

Figure 11: Influence of key characteristics of the upstream material ( $p A 0, p c 4$ and $p f 200)$ in the type of behaviour observed in the CFET

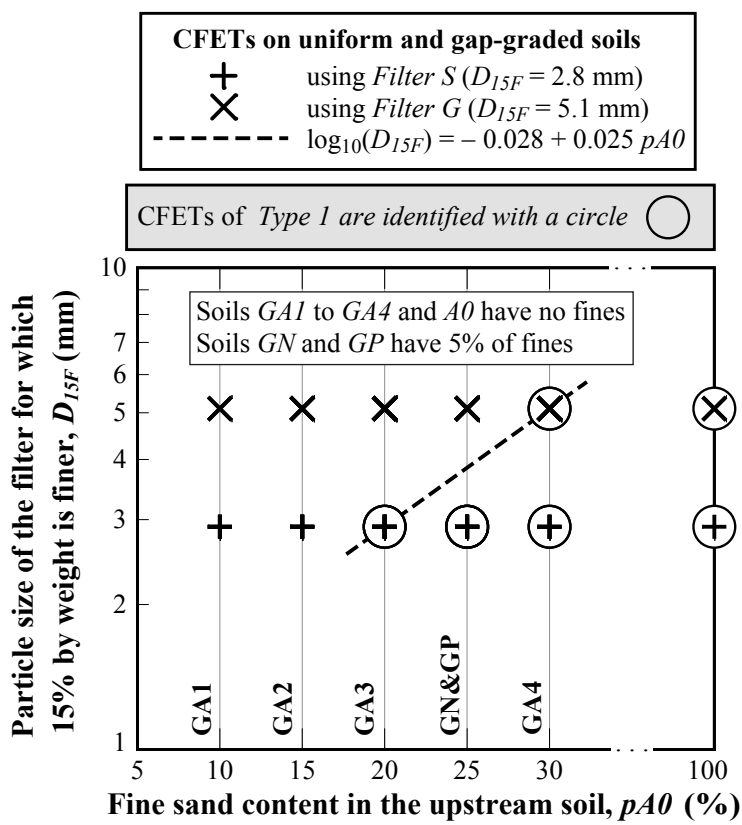

Figure 12: Fine sand content of the upstream soil, $p A 0$, against the $D_{15} \mathrm{~F}$ of the filter, at the start of each CFET on the selected upstream soils, where $D_{i}=12 \mathrm{~mm}$

line in Figure 12. It is noted that, for $D_{i}=16 \mathrm{~mm}$, Type 1 was observed only in tests on soil GA4 together with Filter $\mathrm{S}$. This suggests that the greater the diameter of the pipe in the core, $D_{i}$, the lower must be the value $D_{15 F}$ and/or the higher the value of $p A 0$, for the "crack filling" to be effective.

\section{LIKELIHOOD OF CRACK FILLING BY AN UPSTREAM FILL, $P_{C F}$}

Table 5 shows a classification method proposed for preliminary estimation of $P_{C F} . P_{C F}$ is divided into five intervals with the following qualitative descriptors: very likely, likely, neutral, unlikely, and very unlikely.

The proposed rules rely on the results of the laboratory testing using the CFET, for the conditions examined, considering the characteristics of the critical parameters influencing the "crack-filling" action. These are the fines content, $p f 200$, and the sand content susceptible to suffusion, psand, of the upstream granular soil, and the grain-size of the filter for which $15 \%$ by weight is finer, $D_{15 F}$. In particular, psand is the fraction of sand-size particles that can be transported through the flaw in the core by suffusion. In an early stage, when the flaw is a crack, fine sand $(0.074$ to $0.42 \mathrm{~mm}$ ) is more likely to be transported, whereas, in latter stages, coarser sand may also be transported (i.e., 0.074 to $4.75 \mathrm{~mm}$ ). When a downstream filter or transition granular material is present downstream of the erosion path in the core, the effectiveness of the filter is determined by checking $D_{15 F}$ against the critical parameters of the upstream soil influencing crack filling.

Taking into account the laboratory testing, it is appropriate to consider the likelihood that $P_{C F}$ is equal to zero in cases where no granular material is present at the downstream of the erosion path in the core.

\section{CONCLUSIONS}

The analysis of the results of the CFETs showed that the crack-filling action is mainly controlled by some of the properties of the upstream zone and of the filter. Core soils with an erosion rate index higher than 4 (i.e., moderately slow erosion or less erodible), should not have an influence on the crack-filling action. This is so mainly because the filling mechanism should occur over a very short period.

The formation of a crack/pipe in the core can lead to a considerable increase of the hydraulic gradient at the upstream zone, which can be sufficient, for example, to develop suffusion in a gap-graded soil. For a given gap-graded soil, filter type and flaw size, crack filling is more likely to occur the greater the content of the fine fraction of the grain-size distribution curve. Gap-graded soils with only $5 \%$ of fines appear to have a lower likelihood of being effective at filling in cracks, even if the fines are of a non-plastic nature, 
Table 5: Proposed rules for preliminary estimation of the likelihood of the uniform or gap-graded soil being effective at stopping pipe enlargement in the core, by filling the pipe up to the downstream filter, $P_{C F}$

\begin{tabular}{|c|c|c|c|c|c|}
\hline \multirow{3}{*}{$\begin{array}{l}\text { Embankment zoning } \\
\text { in the erosion path } \\
\text { immediately upstream } \\
\text { of the core * }\end{array}$} & \multicolumn{2}{|c|}{$\begin{array}{l}\text { Key features of the } \\
\text { upstream zone }\end{array}$} & \multicolumn{3}{|c|}{ Embankment zoning in the erosion path at downstream** } \\
\hline & & & \multicolumn{3}{|c|}{ Downstream filter or transition granular material } \\
\hline & $\begin{array}{l}\text { Fines } \\
\text { content, } \\
p f 200\end{array}$ & $\begin{array}{l}\text { Effectiveness } \\
\text { of upstream soil }\end{array}$ & $D_{15 F}<2.9 \mathrm{~mm}$ & Transition & $D_{15 F}>5.1 \mathrm{~mm}$ \\
\hline $\begin{array}{l}\text { Upstream granular zone, } \\
\text { very unlikely to sustain } \\
\text { an open crack/pipe }\end{array}$ & $5 \%$ & $\begin{array}{l}\text { psand }>30 \% \text { and } p f 200=0 \\
\text { Transition } \\
\text { psand }<20 \% \text { and } p f 200=5 \%\end{array}$ & $\begin{array}{l}\text { Very likely } \\
\text { Likely } \\
\text { Unlikely }\end{array}$ & $\begin{array}{l}\text { Likely } \\
\text { Likely-unlikely*** } \\
\text { Unlikely }\end{array}$ & $\begin{array}{l}\text { Unlikely } \\
\text { Unlikely } \\
\text { Very unlikely }\end{array}$ \\
\hline $\begin{array}{l}* P_{C F}=0 \text { for homogen } \\
\text { earth fill, earth fill with c } \\
{ }_{* *} P_{C F}=0 \text { for embankn } \\
* * * \text { If } \log D_{15 F} \text { is lower } \\
\text { otherwise } P_{C F}=\text { unlikel }\end{array}$ & $\begin{array}{l}\text { ous dam, } \\
\text { ore wall, } \\
\text { ents with } \\
\text { han } 0.025\end{array}$ & $\begin{array}{l}\text { arth fill with toe drain, earth fill } \\
\text { id hydraulic fill. } \\
\text { o granular material at downstrea } \\
\text { sand - } 0.028 \text { (see Fig. 12), and t } \\
\text { tively. }\end{array}$ & $\begin{array}{l}\text { th horizontal drai } \\
\text { of the core. } \\
\text { ere are no fines or }\end{array}$ & es are non-plastic & $\begin{array}{l}\text { ll, puddle core } \\
\text { hen } P_{C F}=\text { likely, }\end{array}$ \\
\hline
\end{tabular}

than a gap-graded soil of similar grain-size distribution curve but with no fines.

The relation between the content of sand that is susceptible to suffusion of the granular upstream zone and the equivalent diameter $D_{15 F}$ of the filter appears to be more relevant, for assessment of the likelihood of crack filling to occur, than the evaluation of the conceptual erosion filter boundaries. For a given flaw size and loading condition, the higher the content of sand susceptible to suffusion, and the lower the $D_{15 F}$, the greater are the chances of the washed in particles being caught at the filter face, and filling in the flaw in the core.

The proposed rules give dam engineers a tool for a preliminary estimation of the likelihood of the crackfilling action by an upstream gap-graded soil, and for decision-making about the potential of a certain upstream material to limit the progression of erosion in concentrated leaks. They can be very useful for the estimation of the overall probability of failure of embankment dams by internal erosion, and for the design phase of a transition zone located upstream of the core.

However, in cases involving materials with grainsize distribution substantially different from those of the soils examined, and for important design decisions, it is advocated that doing the CFET is preferable to using the proposed rules. The test is simple to carry out, and is considered to be more reliable for evaluation of the evolution of the internal erosion process.

\section{REFERENCES}

Correia dos Santos, R. (2014). Experimental investigation on limitation of the progression of internal erosion in zoned dams. Phd thesis.

Correia dos Santos, R., L. Caldeira, \& E. Maranha das Neves (2012). Influência da compactao na erodibilidade de um solo parcialmente saturado sujeito a uma fuga concentrada (in portuguese). Revista Geotecnia 125, 36.
Correia dos Santos, R., L. Caldeira, \& E. Maranha das Neves (2014). Laboratory test for evaluating limitation of flows during internal erosion in zoned dams. Geotechnical Testing Journal 37(3), 463-476.

Correia dos Santos, R., L. Caldeira, \& E. Maranha das Neves (2015a). Experimental study on crack filling by upstream fills in dams. Géotechnique 65(3), 218-230.

Correia dos Santos, R., L. Caldeira, \& E. Maranha das Neves (2015b). Laboratory test for evaluating crack filling during internal erosion in zoned dams. Geotechnical Testing Journal 38(6), 14.

Fell, R., M. Foster, J. Cyganiewicz, G. Sills, N. Vroman, \& R. Davidson (2008). A unified method for estimating probabilities of failure of embankment dams by internal erosion and piping (dated august 21). Technical Report UNSW Document UNICIV R 446, The University of New South Wales.

Foster, M. \& R. Fell (2001). Assessing embankment dam filters that do not satisfy design criteria. Journal of Geotechnical and Geoenvironmental Engineering 127(5), 398-407.

Foster, M., R. Fell, \& M. Spannagle (2000). The statistics of embankment dam failures and accidents. Canadian Geotechnical Journal 37, 1000-1024.

Gillon, M. (2007). Re-evaluation of internal erosion incidents at Matahina Dam, New Zealand, pp. 115-132. Taylor Francis.

ICOLD (2013). Internal erosion of dams, dikes and their foundations. volume 1: Internal erosion processes and engineering assessment. bulletin 164 (dated january 24). Technical report, International Commission on Large Dams.

Maranha das Neves, E. (1987, September). Discussion report: Ground water effects in geotechnical engineering.

Maranha das Neves, E. (1989). Analysis of crack erosion in dam cores: the crack erosion test, pp. 284-298. São Paulo, Brazil: Editora Edgard Blucher Ltda.

Maranha das Neves, E. (1991). Comportamento de barragens de terra-enrocamento (in Portuguese). Phd thesis.

Sherard, J. L. (1973). Embankment dam cracking. In Embankment Dam Engineering. New York: Hirschfeld and Poulos eds. John Wiley \& Sons.

USBR $(2011,254)$. Design standards no. 13, embankment dams, chapter 5 - protective filters. Technical report, Bureau of Reclamation, U. S. Department of the Interior.

Vaughan, P. R. \& H. Soares (1982). Design of filters for clay cores of dams. Journal of the Geotechnical Engineering Division, ASCE 108(GT1), 17-31.

Wan, C. F. \& R. Fell (2004). Laboratory tests on the rate of piping erosion of soils in embankment dams. Geotechnical Testing Journal 27(3), 295-303. 